\title{
Combined Life Cycle Assessment and Life Cycle Costing in the Eco-Care-Matrix: A case study on the performance of a modernized manufacturing system for glass containers
}

\author{
Auer, Johannes; Bey, Niki; Schäfer, Johannes-Marius
}

Published in:

Journal of Cleaner Production

Link to article, DOI:

10.1016/j.jclepro.2016.08.096

Publication date:

2017

Document Version

Peer reviewed version

Link back to DTU Orbit

Citation (APA):

Auer, J., Bey, N., \& Schäfer, J-M. (2017). Combined Life Cycle Assessment and Life Cycle Costing in the EcoCare-Matrix: A case study on the performance of a modernized manufacturing system for glass containers. Journal of Cleaner Production, 141, 99-109. https://doi.org/10.1016/j.jclepro.2016.08.096

\section{General rights}

Copyright and moral rights for the publications made accessible in the public portal are retained by the authors and/or other copyright owners and it is a condition of accessing publications that users recognise and abide by the legal requirements associated with these rights.

- Users may download and print one copy of any publication from the public portal for the purpose of private study or research.

- You may not further distribute the material or use it for any profit-making activity or commercial gain

- You may freely distribute the URL identifying the publication in the public portal 
Wordcount:

Manuscript: 7844

Figure captions: 253

Total: 8097 


\title{
Combined Life Cycle Assessment and Life Cycle Costing in the Eco-Care-Matrix: A case study on the performance of a modernized manufacturing system for glass containers
}

\author{
Authors: \\ Johannes $\underline{\text { Auer }}^{1,2}$; Niki $\underline{B e y}^{2}$; Johannes-Marius $\underline{\text { Schäfer }}^{3}$ \\ (Family names are underlined)
}

\begin{abstract}
Affiliation:
${ }^{1}$ Department for Environment, Health \& Safety, Process Industries \& Drives Division, Siemens AG, 90475 Nuremberg, Germany

${ }^{2}$ Department of Management Engineering, Division for Quantitative Sustainability Assessment, Technical University of Denmark, 2800 Kgs. Lyngby, Denmark

${ }^{3}$ Faculty for Environmental Science, TU Dresden, 01062 Dresden, Germany
\end{abstract}

\section{Corresponding Author:}

Johannes Auer, Contact:

E-mail: johau@dtu.dk or Johannes.auer@siemens.com; Mobile: +49(0)162 4096187

Address: Siemens AG, PD EHS, Gleiwitzerstr. 555, 90475 Nuremberg, Germany

\section{Funding:}

This research did not receive any specific grant from funding agencies in the public, commercial, or not-for-profit sectors. 
Auer J, Bey N, Schäfer J-M (2016); Combined Life Cycle Assessment and Life Cycle Costing in the EcoCare-Matrix: A case study on the performance of a modernized manufacturing system for glass containers Journal of Cleaner Production, Vol. 141, 10 January 2017, pp. 99-109 (online 1 Sept. 2016) http://dx.doi.org/10.1016/j.jclepro.2016.08.096

\section{Abstract}

The objects of Life Cycle Assessment (LCA) case studies are often individual components or individual products. Studies focusing on larger industrial manufacturing systems are relatively rare. The purpose of this case study was to assess environmental and cost-related performance of an updated complex manufacturing system for glass containers (i.e. jars, glass bottles, etc.) compared to the predecessor manufacturing system. The objective was also to identify the most relevant drivers for the environmental and the cost profile of the system solution in application context by the means of Life Cycle Assessment, as well as Life Cycle Costing (LCC). The results were then to be displayed in an Eco-Care-Matrix (ECM) in order to quantitatively visualize the improvements when comparing the updated manufacturing system to the previous one and they were to be discussed in terms of (i) ecodesign levers, (ii) efficiency of the LCA process and (iii) their relevance for the speed and cost of the decision-making process. The LCA results of the production stage of the optimized components showed that the largest contributors to the potential environmental impact of the manufacturing system are the motors due to their material composition, number and mass. The use stage was subsequently recognized as the dominant life cycle stage with Global Warming Potential (GWP) as the leading indicator, due to the long service life (20 years) and the corresponding energy consumption. The analysis of a produced glass bottle's GWP showed that it was reduced by about $40 \%$ through optimizing the production system. The LCC showed that the modernization pays off after about five years of service life and that the decision for making an investment should not only be based on the required capital expenditure (CAPEX). Rather, operation expenditure (OPEX) should also be considered in order to reflect the savings gained from lower operating costs, which compensate relatively quickly any higher initial expenditure or initial investment. In order to apply Life Cycle Assessment on larger-scale industrial systems, smart and pragmatic LCA modeling approaches have to be developed and adopted, balancing accuracy of results against efficiency in achieving them. An adequate ecological-and-economic assessment tool would reduce the time and effort when making decisions in this context.

\section{Keywords:}

Life Cycle Assessment (LCA)

Life Cycle Costing (LCC)

manufacturing system

individual section machine (IS machine) 
Auer J, Bey N, Schäfer J-M (2016); Combined Life Cycle Assessment and Life Cycle Costing in the EcoCare-Matrix: A case study on the performance of a modernized manufacturing system for glass containers Journal of Cleaner Production, Vol. 141, 10 January 2017, pp. 99-109 (online 1 Sept. 2016) http://dx.doi.org/10.1016/j.jclepro.2016.08.096

\section{Eco-Care-Matrix (ECM)}


Auer J, Bey N, Schäfer J-M (2016); Combined Life Cycle Assessment and Life Cycle Costing in the EcoCare-Matrix: A case study on the performance of a modernized manufacturing system for glass containers Journal of Cleaner Production, Vol. 141, 10 January 2017, pp. 99-109 (online 1 Sept. 2016) http://dx.doi.org/10.1016/j.jclepro.2016.08.096

\section{Introduction}

Today's global challenges involve factors such as population growth and the accompanying increase in consumption of resources and air pollution, including climate change (UN, 2013). As a result, the awareness for environmental issues is steadily increasing, and customers as well as authorities are becoming more interested in the environmental footprint of products, services and technologies (Chomkhamsri and Pelletier, 2011). Due to customer demands, sector-specific initiatives and legal requirements, the current challenges of the production industry are intensifying, while new challenges are also evolving. Various approaches have been developed in the different sectors; for instance in transportation (Dobranskyte-Niskota et al., 2007), the automotive industry (Moah and Kanaroglou, 2009) is in need of sustainable electrical cars concepts (Strømman et al., 2012);. In the power generation sector, the increase of renewable power generation technologies calls for improvements in regard to resource utilization (Stoppato, 2006), while sustainability in the manufacturing sector is challenged (Namibar, 2010) especially by energy consumption as a major cause of environmental impacts and contributions to climate change, and thus is sought to be reduced, as for instance in the pulp and paper industry (Farla et al., 1997), the steel and iron industry (Mao et al., 2013), mining (Sarapulov et al., 2015) or maching and processing of materials (Hülsemeyer et al., 2015).

An example instrument to lower energy consumption are the European Union's Ecodesign Directive (2009/125/EC) and the corresponding measures to establish mandatory ecodesign requirements for energy-related and energy-using products sold inside the European Union. Their objective is to reduce the energy consumption of products, but also to enhance the environmental performance through improved material use and the ability to recycle these products (EC, 2011). Furthermore, environmental footprinting has recently become more popular, as laid down for instance in the EU PEF initiative (Product Environmental Footprints) (EC, 2013). These current approaches focus more or less on the single product and its environmental impact and resource consumption. However, they do not appropriately take into account the performance of the system, which the product is intended to be used in, i.e. they only insufficiently regard the context of target applications. Requirements to and performance of for instance an electric motor may, however, differ widely depending on whether the motor is part of a system, where it is used occasionally vs. a system where it runs constantly. 
Auer J, Bey N, Schäfer J-M (2016); Combined Life Cycle Assessment and Life Cycle Costing in the EcoCare-Matrix: A case study on the performance of a modernized manufacturing system for glass containers Journal of Cleaner Production, Vol. 141, 10 January 2017, pp. 99-109 (online 1 Sept. 2016) http://dx.doi.org/10.1016/j.jclepro.2016.08.096

This leads to a demand for products that are sustainability-optimized in the system design perspective, and consequently, to a demand for practical methods for i) evaluating the environmental footprint in application context, ii) considering at least the most relevant aspects of this in engineering and iii) evaluate if a refurbishing of existing system would make sense. Addressing this background, the aim of the research presented here was to apply the Eco-Care-Matrix (ECM) in a case study of a manufacturing system for glass containers (i.e. bottles, jars, etc.). With the Eco-Care-Matrix, two (product) systems can be compared in terms of their economic and environmental performance (Wegener et al., 2009). The two key elements in the ECM are Life Cycle Assessment (LCA) based on ISO 14040/14044 and a Life Cycle Costing (LCC) approach based on a cost breakdown structure (Hui and Mohammed, 2015). The intention was to derive the most relevant environmental impact issues and their drivers in order to facilitate ecodesign at the system level in the application context. By linking LCA and LCC results in the ECM, different design options can be compared in terms of environmental and economic performance.

The manufacturing system under study is based on individual section machines (IS machines), as used in the container glass industry (Diehm, 2007). Such machines enable a simultaneous and automatic production of container glass. In this case the previously used hydraulic and pneumatic system has been modernized by employing innovative electronic servo drive technology and a motion control concept (Sklostroj, 2015), which is part of the Siemens integrated drive system philosophy (IDS). IDS can be classified as an integrated product service system (IPSS) (Meier et al. 2010). With IPSS, resources can be used more efficiently (Lindahl et al., 2014), especially when these aspects are considered in the system's components development (Bey and McAloone, 2006), as for instance machine availability and productivity may be increased by horizontally integrating the drives, vertically integrating the whole automation environment and integrating smart services across (Siemens, 2015).

The paper is organized as follows: In Section 2, case study design and applied methods are described and explained. Section 3 then presents the results obtained by applying the methods and Section 4 discusses these in regard to potential generalization, uncertainties and sensitivity. Finally, Section 5 concludes on the results and gives an outlook on future work. 
Auer J, Bey N, Schäfer J-M (2016); Combined Life Cycle Assessment and Life Cycle Costing in the EcoCare-Matrix: A case study on the performance of a modernized manufacturing system for glass containers Journal of Cleaner Production, Vol. 141, 10 January 2017, pp. 99-109 (online 1 Sept. 2016) http://dx.doi.org/10.1016/j.jclepro.2016.08.096

\section{Methodology}

\subsection{Study Design}

The aim of this case study was to quantitatively assess the benefits of the modernized manufacturing system when comparing it to the predecessor system in terms of ecological and economic parameters by employing the Eco-Care-Matrix (ECM), based on LCA and LCC. The greatest challenge was expected to be the complexity of the system due to the sheer amount of components involved. Now, starting from a detailed LCA of the servo drive solution, the study was designed to evaluate the most relevant life cycle stage - and in turn, it's most relevant potential impact, as well as the corresponding drivers. Data was then to be captured for comparing the performance of the servo drive solution with the predecessor system in the identified most relevant life cycle stage, both in the environmental as well as in the economic domains, and visualized in the ECM. The study was conducted in 2014/2015 with data captured between 2010 and 2015. Based on foreseeable changes in the technological environment, especially in terms of power generation and the increased contribution of renewable sources, it is assumed that the results will remain valid until 2020 at the latest.

The key methods chosen to address the research topic are LCA (ISO 14040, 2006) and LCC (Woodward, 1997). The environmental and economic benefits of the previous and the updated systems are identified and demonstrated using the ECM. Additionally, the level of resources required for these types of studies are to be discussed and mirrored against the results that have been obtained.

\subsection{Manufacturing System}

Figure 1 shows the concept of IS machines as used in container glass manufacturing (Trifonova and Ishun'kina, 2007), while Figure 2 provides a schematic overview of the solution with servo drive components, and Figure 3 shows the new innovated solution. The predecessor solution, mostly involving pneumatic and hydraulic systems, will be referred to as "System A" and the successor system, using mostly electric servo drives, will be referred to as "System B". 
Auer J, Bey N, Schäfer J-M (2016); Combined Life Cycle Assessment and Life Cycle Costing in the EcoCare-Matrix: A case study on the performance of a modernized manufacturing system for glass containers Journal of Cleaner Production, Vol. 141, 10 January 2017, pp. 99-109 (online 1 Sept. 2016) http://dx.doi.org/10.1016/j.jclepro.2016.08.096

The most critical part of the manufacturing process is the shaping of the glass containers. By using servo drive solutions, the requirements relating to the shaping process, e.g. availability, throughput and robustness, can be met and increased compared to pneumatic or hydraulic solutions. The use of the control system enables several benefits to be obtained for the IS machine, e.g. generation of even and consistent gobs (i.e. liquid glass pieces) by the plunger as well as accurate and dynamic cutting using the shears. This ensures a reliable distribution to all sections of the machine and thermal stability of the whole system, therefore increasing the quality of the end product and the yield, which in turn improves the productivity of the overall system.

Further, the use of smart automation and motion control components, supported by sensors and communication interfaces, allows individual sections or parts of the system to be maintained without putting the whole production on hold (Siemens, 2015).

The fully automated production system consists of a central cabinet module for feeding the material into eight individual sections for forming, which leads to an output of about one glass container per second. In the predecessor system, actuators and controls were driven by compressed air, whereas in the innovated version, these are driven by highly efficient electric servomotors.

\subsection{Life Cycle Assessment (LCA)}

LCA is a method to quantify the environmental impact of products, systems and services over the entire life cycle in order to support sustainable development in organizations (Hauschild et al., 2005), as for instance in glass production (Pulselli et al., 2009). The LCA was conducted according to the principles laid down in the international standards ISO 14040 and 14044 (ISO 14040, 2006), as well as the ILCD handbook (EC, 2010) and the recently published product category rules for motor systems, standardized in EN 50598-3 (EN50598-3, 2015). The software GABI6 and the GABI life cycle inventory databases were used for the modeling (Thinkstep, 2015).

\subsubsection{Goal and scope}

The goal of the case study was basically to identify a) the most relevant life cycle stage of the system relating to the environment and the economics and b) the components and environmental impact categories with the highest contributions to the entire system. Additionally, the results were then to be c) broken down to one glass container produced on "System A" and on "System B", respectively. By comparing the previous so- 
Auer J, Bey N, Schäfer J-M (2016); Combined Life Cycle Assessment and Life Cycle Costing in the EcoCare-Matrix: A case study on the performance of a modernized manufacturing system for glass containers Journal of Cleaner Production, Vol. 141, 10 January 2017, pp. 99-109 (online 1 Sept. 2016) http://dx.doi.org/10.1016/j.jclepro.2016.08.096

lution with the innovated one, the expected benefits of the servo drive solution were to be quantitatively evaluated based on the results of the LCA. To achieve this, the perspective of a system refurbishment was taken, which means that the servo drive components were considered as addition to an identical background system (i.e. the manufacturing peripherals), which was identical for the two systems. Since the detailed LCA accounted the modernized IDS components and electric drives in addition to the background system, i.e. as extra burden, vs. the potential benefits resulting from their use, the described comparison can be considered as a worst-case scenario. In real life, the basis for the comparison would be two different systems - the individual section machine, based mainly on pneumatic drive technology and the individual servo section machine, utilizing electric servo drive technology, offered by the OEM. In the case that the increased performance offsets the additional economic and ecological impact, then it could make sense to upgrade existing machines with servo drive components. This is summarized in Table 1.

The functional unit for the study was defined as manufacturing a defined number of glass containers in a certain time frame on a combined system. The number of glass containers manufactured over the system lifetime is 2.88 billion $(2.88 \mathrm{E}+09)$, based on a throughput of 400 bottles per minute for the servo drive system, by operating 6,000 hours per annum for 20 years.

Table 1: Overview of the components. Cells with a grey background are included in the scope of the LCA, whereas the disregarded background system is similar in systems A and $\mathrm{B}$.

\begin{tabular}{|l|l|l|}
\hline \multicolumn{1}{|c|}{ Scope of LCA } & \multicolumn{1}{|c|}{ System A } & \multicolumn{1}{c|}{ System B } \\
\hline $\begin{array}{l}\text { Manufacturing/construction } \\
\text { stage }\end{array}$ & $\begin{array}{l}\text { Not considered; no data } \\
\text { available }\end{array}$ & $\begin{array}{l}\text { Servo drive components: } \\
\text { PLC; frequency converters; } \\
\text { servomotors }\end{array}$ \\
\hline Use stage & $\begin{array}{l}\text { Measurements: Performance } \\
\text { data from OEM }\end{array}$ & $\begin{array}{l}\text { Measurements: Performance } \\
\text { data from OEM }\end{array}$ \\
\hline End-of-life stage & $\begin{array}{l}\text { Not considered; no data } \\
\text { available }\end{array}$ & $\begin{array}{l}\text { Approximated, based on de- } \\
\text { tailed assessment of key } \\
\text { components }\end{array}$ \\
\hline
\end{tabular}

The system boundaries for the servo drive components were set according to EN505983 , corresponding to a cradle-to-grave approach, including the extraction of resources, 
Auer J, Bey N, Schäfer J-M (2016); Combined Life Cycle Assessment and Life Cycle Costing in the EcoCare-Matrix: A case study on the performance of a modernized manufacturing system for glass containers Journal of Cleaner Production, Vol. 141, 10 January 2017, pp. 99-109 (online 1 Sept. 2016) http://dx.doi.org/10.1016/j.jclepro.2016.08.096

the manufacturing of the equipment, the use stage (being the production of glass containers) and the final end-of-life stage incl. recycling and disposal.

\subsubsection{Life cycle inventory}

The life cycle inventory is the basis for the life cycle impact assessment (LCIA) (ISO 14044, 2006). Table 1 gives an overview of the servo drive components used to modernize the production system, and the allocation of the components to certain functions. These components are the basis for the comparative LCA to evaluate the additional burden in the manufacturing stage by enhancing the system with electric servo drives and motion control. The total weight of the components used to modernize the system was about 2.2 tons.

Table 2: Overview of the servo drive components and their function group, needed to modernize the IS machine.

\begin{tabular}{|l|r|r|rr|}
\hline $\begin{array}{l}\text { Associated function group: } \\
\text { Description }\end{array}$ & $\begin{array}{l}\text { Amount [no. } \\
\text { of pieces] }\end{array}$ & $\begin{array}{l}\text { Mass [kg] per } \\
\text { function group }\end{array}$ & $\begin{array}{l}\text { Percentage by } \\
\text { mass of the whole } \\
\text { system }\end{array}$ \\
\hline $\begin{array}{l}\text { Automation Controls \& Com- } \\
\text { munication (ACC); needed to } \\
\text { control/automate the whole man- } \\
\text { ufacturing system }\end{array}$ & 292 & 49.38 & 2.26 \\
\hline $\begin{array}{l}\text { Motion Controls (MC); needed } \\
\text { for the control including synchro- } \\
\text { nization of the movement of the } \\
\text { drive systems }\end{array}$ & 18 & 56.25 & 2.57 \\
\hline $\begin{array}{l}\text { Variable Speed Drives (VSD); } \\
\text { allow exact control of the torque } \\
\text { and speed of the motors }\end{array}$ & 145 & 672.50 & 30.77 \\
\hline $\begin{array}{l}\text { Motors; transfer electrical energy } \\
\text { to mechanical power in order to } \\
\text { move parts }\end{array}$ & 103 & $1,385.64$ & 100 \\
\hline $\begin{array}{l}\text { Switch \& Control Gear (S\&CG); } \\
\text { needed to start, monitor and } \\
\text { break operations }\end{array}$ & 632 & $2,185.82$ & & \\
\hline Total & & & & \\
\hline
\end{tabular}


Auer J, Bey N, Schäfer J-M (2016); Combined Life Cycle Assessment and Life Cycle Costing in the EcoCare-Matrix: A case study on the performance of a modernized manufacturing system for glass containers Journal of Cleaner Production, Vol. 141, 10 January 2017, pp. 99-109 (online 1 Sept. 2016) http://dx.doi.org/10.1016/j.jclepro.2016.08.096

The servo drive components were modelled based on existing Siemens data and aggregated GABI data sets, e.g. for assembly energy, metals and other commodities/materials. As already mentioned above, the basis for the assessment of the use stage was data provided by the OEM supplying the modernized IS machine (System B, IS machine with servo drive components), which state a $40 \%$ increase in energy efficiency and a $15 \%$ increase in machine availability (Siemens, 2015). To assess the energy consumption of the drive trains in the use stage, the SIZER engineering tool (SIZER, 2015) was used to model the corresponding profile in operation. The efficiency of the servomotors was conservatively set to $90 \%$. The energy consumption of System A was then determined to be $140 \%$ of the calculated consumption of System B. The potential environmental impact of the two systems was then calculated using EU27 power mix.

\subsubsection{Life cycle impact assessment}

In the impact assessment, the following impact categories from the CML2001 characterization model of April 2013 as implemented in GABI, were evaluated in detail:

- Eutrophication potential (EP),

- Photochemical ozone creation potential (POCP),

- Global warming potential (GWP) and

- Acidification potential (AP).

The characterization model was chosen due to the fact that data for some of the servo drive components had already been assessed based on this CML model, and in order to aggregate the scores meaningfully, the characterization models have to match. The categories were chosen since they are strongly related to electricity production, since power consumption is known to be a major driver when it comes to the environmental impact of the type of equipment under consideration.

\subsection{Life Cycle Costing (LCC)}

An LCC is a comprehensive decision-making tool for calculating the total costs which are generated over the entire lifetime of products and services (Kádárová et al., 2015). The execution of an LCC enables the potential cost drivers and cost savings of a product or service to be identified over its entire life cycle. By comparing different alternatives, the most cost-effective option can be identified. A variety of methods and approaches has been developed under the umbrella of LCC, due to the heterogeneity and applica- 
Auer J, Bey N, Schäfer J-M (2016); Combined Life Cycle Assessment and Life Cycle Costing in the EcoCare-Matrix: A case study on the performance of a modernized manufacturing system for glass containers Journal of Cleaner Production, Vol. 141, 10 January 2017, pp. 99-109 (online 1 Sept. 2016) http://dx.doi.org/10.1016/j.jclepro.2016.08.096

tion scenarios of the businesses being analyzed. The common aim of the various LCC approaches is to determine the most cost-effective and thus most competitive solution of a product or service (Woodward, 1997). In this case, the LCC, consisting of CAPEX and OPEX (i.e. capital and operational expenditures, respectively), were derived by using a cost breakdown structure (CBS), taking into consideration the principles laid down by Hui and Mohammed (2015), in order to analyze the cost-benefit ratio in terms of the pay-off period. To estimate the total energy costs of the combined system, a price of $€ 0.12$ for one $\mathrm{kWh}$ of electric energy as an average value within the EU was used as basis (Eurostat: EU-28; $2^{\text {nd }}$ half of 2014) based on (EU, 2015).

\subsection{Eco-Care-Matrix}

The Eco-Care-Matrix (ECM) is used as a decision-making support tool in portfolio management as well as product lifecycle management, including engineering. It plots the ecological impact/benefits over economic performance of a product or system compared against a reference, for instance an outdated or an alternative technology. The application of ECM supports the development of products and services that have been improved from environmental and cost efficiency perspectives. The ECM can therefore be seen as an Eco-efficiency tool, including the challenges associated with the concept of Eco-efficiency, described by (Ehrenfeld, 2005) and further introduced with applications by (Huppes and Ishikawa, 2007).

The results from LCA and LCC are used as basis to assess the environmental benefits over the economic benefits. While the $\mathrm{x}$-axis represents customer benefit as a change in system costs, the y-axis expresses environmental compatibility of a considered application to the reference point. Environmental benefit can include a combination of any environmental impact. An example for an Eco-Care-Matrix is shown in Figure 4.

The reference point (e.g. traditional technology) is located at the center of the matrix. While technology/scenario $\mathrm{C}$ has higher customer benefits than technologies/scenarios $\mathrm{A}$ and $\mathrm{B}$, environmental benefits of technologies/scenarios $\mathrm{A}$ and $\mathrm{B}$ are higher compared to technology/scenario C. A technology/scenario then can be defined as "green solution", if it's environmental performance is better than the reference at same level of customer satisfaction (Wegener et al., 2011).

In order to achieve a meaningful application - and therefore robust interpretation of the results of the ECM - it is crucial that the whole framework of the underlying LCA and 
Auer J, Bey N, Schäfer J-M (2016); Combined Life Cycle Assessment and Life Cycle Costing in the EcoCare-Matrix: A case study on the performance of a modernized manufacturing system for glass containers Journal of Cleaner Production, Vol. 141, 10 January 2017, pp. 99-109 (online 1 Sept. 2016) http://dx.doi.org/10.1016/j.jclepro.2016.08.096

LCC study is consistent, i.e. uses the same system delimitations, data sources/types, background assumptions, etc. 
Auer J, Bey N, Schäfer J-M (2016); Combined Life Cycle Assessment and Life Cycle Costing in the EcoCare-Matrix: A case study on the performance of a modernized manufacturing system for glass containers Journal of Cleaner Production, Vol. 141, 10 January 2017, pp. 99-109 (online 1 Sept. 2016) http://dx.doi.org/10.1016/j.jclepro.2016.08.096

\section{$3 \quad$ Results}

\subsection{Life Cycle Assessment}

\subsubsection{Manufacturing}

The life cycle impact assessment (LCIA) was performed for each key component corresponding to the LCA approach described in the previous chapter.

The various components from the five function groups, as shown in Table 2, were clustered into two the clusters electronic devices (VSDs, MC, ACC) and electromechanical devices (motors, S\&CG) and handled as laid out in (Hermann et al., 2012). The material composition within the two clusters is more or less the same. The electromechanical components predominantly comprise high grade metals and plastics, and the electronic devices comprise electronic parts that are soldered on printed circuit boards and accommodated in a plastic housing. Table 3 summarizes the results of the LCIA of the manufacturing stage - quantifying eutrophication potential (EP), photochemical oxidation potential (PCOP), acidification potential (AP) and global warming potential (GWP) - for each function group cluster, while Table 4 lists the function groups' potential impacts related to their amount in the system, using the components' weight (within the function group) to build the relation.

Table 3: LCIA scores in the chosen impact categories aggregated for each function group.

\begin{tabular}{|l|c|c|c|c|c|c|}
\hline \multicolumn{1}{|c|}{$\begin{array}{c}\text { Impact } \\
\text { category }\end{array}$} & Motors & VSDs & MC & ACC & S\&CG & Total \\
\hline $\begin{array}{l}\mathrm{EP} \\
{[\mathrm{kg} \mathrm{PO} 4-\mathrm{Eqv} .]}\end{array}$ & $6.19 \mathrm{E}+01$ & $4.10 \mathrm{E}+00$ & $1.55 \mathrm{E}+00$ & $7.70 \mathrm{E}-01$ & $4.00 \mathrm{E}-01$ & $6.87 \mathrm{E}+01$ \\
\hline $\begin{array}{l}\text { PCOP [kg } \\
\mathrm{C} 2 \mathrm{H} 4-\mathrm{Eqv} .]\end{array}$ & $8.24 \mathrm{E}+01$ & $5.81 \mathrm{E}+00$ & $1.35 \mathrm{E}+00$ & $7.50 \mathrm{E}-01$ & $3.90 \mathrm{E}-01$ & $9.07 \mathrm{E}+01$ \\
\hline $\begin{array}{l}\text { AP [kg SO} 2^{-} \\
\text {Eqv.] }\end{array}$ & $8.18 \mathrm{E}+02$ & $7.91 \mathrm{E}+01$ & $2.07 \mathrm{E}+01$ & $1.29 \mathrm{E}+01$ & $6.75 \mathrm{E}+00$ & $9.38 \mathrm{E}+02$ \\
\hline $\begin{array}{l}\text { GWP [kg CO} 2_{-}- \\
\text {Eqv.] }\end{array}$ & $1.92 \mathrm{E}+05$ & $1.21 \mathrm{E}+04$ & $3.15 \mathrm{E}+03$ & $1.56 \mathrm{E}+03$ & $8.17 \mathrm{E}+02$ & $2.09 \mathrm{E}+05$ \\
\hline
\end{tabular}


Auer J, Bey N, Schäfer J-M (2016); Combined Life Cycle Assessment and Life Cycle Costing in the EcoCare-Matrix: A case study on the performance of a modernized manufacturing system for glass containers Journal of Cleaner Production, Vol. 141, 10 January 2017, pp. 99-109 (online 1 Sept. 2016) http://dx.doi.org/10.1016/j.jclepro.2016.08.096

Table 4: Normalized LCIA scores using the component weight per function group as normalization factor.

\begin{tabular}{|l|r|r|r|r|r|r|}
\hline \multicolumn{1}{|c|}{$\begin{array}{c}\text { Impact } \\
\text { category }\end{array}$} & Motors & \multicolumn{1}{c|}{ VSDs } & \multicolumn{1}{c|}{ MC } & \multicolumn{1}{c|}{ ACC } & S\&CG & Total \\
\hline Weight [kg] & 1,385 & 672 & 56 & 49 & 22 & 2,184 \\
\hline $\begin{array}{l}\text { EP } \\
\text { [kg PO4-Eqv. / } \\
\text { kg Mass] }\end{array}$ & $4.47 \mathrm{E}-02$ & $6.10 \mathrm{E}-03$ & $2.77 \mathrm{E}-02$ & $1.57 \mathrm{E}-02$ & $1.82 \mathrm{E}-02$ & $3.15 \mathrm{E}-02$ \\
\hline $\begin{array}{l}\text { PCOP [kg } \\
\text { C2H4-Eqv. / kg } \\
\text { Mass] }\end{array}$ & $5.95 \mathrm{E}-02$ & $8.65 \mathrm{E}-03$ & $2.41 \mathrm{E}-02$ & $1.53 \mathrm{E}-02$ & $1.77 \mathrm{E}-02$ & $4.15 \mathrm{E}-02$ \\
\hline $\begin{array}{l}\text { GWP [kg CO }- \\
\text { Eqv. / kg Mass] }\end{array}$ & $5.91 \mathrm{E}-01$ & $1.18 \mathrm{E}-01$ & $3.70 \mathrm{E}-01$ & $2.64 \mathrm{E}-01$ & $3.07 \mathrm{E}-01$ & $4.29 \mathrm{E}-01$ \\
\hline $\begin{array}{l}\text { AP [kg SO}- \\
\text { Eqv./ kg Mass] }\end{array}$ & $1.38 \mathrm{E}+02$ & $1.80 \mathrm{E}+01$ & $5.62 \mathrm{E}+01$ & $3.19 \mathrm{E}+01$ & $3.71 \mathrm{E}+01$ & $9.58 \mathrm{E}+01$ \\
\hline
\end{tabular}

Figure 5 shows the contribution per function group as a percentage for the various impact categories, using the LCIA scores related to the weight of the functionality from Table 4. The contribution of the function groups to each impact category is more or less comparable, but it also shows that the motion control functionality has relatively high LCIA scores related to its weight.

With reference to the GWP, motors made up the largest part of all components with $1.92 \mathrm{E}+05 \mathrm{~kg} \mathrm{CO}$-eqv., which represents $92 \%$ for the manufacturing stage $(2.09 \mathrm{E}+05$ $\mathrm{kg} \mathrm{CO}$-eqv. in total). Frequency converters with $1.21 \mathrm{E}+04 \mathrm{~kg} \mathrm{CO}$-eqv. represented the second highest contribution to the GWP. Evaluating the impacts broken down according to the weight of the components verifies the significance of the motors (or the drive system) in the system context.

To put the result into a broader perspective and to allow a comparison across impact categories, external normalization factors for the EU $(25+3)$ from (Sleeswijk et al., 2007) were applied. The results are shown in Figure 6.

Looking at the evaluated impact categories, AP, POCP and GWP are the most relevant impact categories with a similar order of magnitude because they have the highest share 
Auer J, Bey N, Schäfer J-M (2016); Combined Life Cycle Assessment and Life Cycle Costing in the EcoCare-Matrix: A case study on the performance of a modernized manufacturing system for glass containers Journal of Cleaner Production, Vol. 141, 10 January 2017, pp. 99-109 (online 1 Sept. 2016) http://dx.doi.org/10.1016/j.jclepro.2016.08.096

to the overall contribution. For a better overview and due to interdependencies between the four impact categories (e.g. all energy-related), results are shown and described in the following in terms of the GWP as leading indicator and are representative for the discussion on the environmental aspects of the combined system. The results of the remaining environmental impact categories supported the statement that motors - respectively the drive system - have the highest environmental impact of the overall system.

\subsubsection{Usage}

For the assessment of the use stage, the power consumption of all components was screened (i.e. calculated, and not measured) and put in context with the application scenario. The power consumption of 256 components out of 632 was analyzed. Cables and memory cards were excluded along with the power consumption of the drive system, which was separately analyzed in detail. The analysis indicated a mean power consumption of 6 Watts per hour for each component, estimated based on the data obtained from data sheets. This then leads to total power consumption of 10,000 kWh/y for controls, communication and the other automation components. SIZER was now used to model the application and the corresponding power consumption (including losses) for the drive systems in total, based on the parameters mentioned above. A power consumption of about 534,600 kWh/y was obtained. The values were added leading to the total system power consumption of 544,600 kWh/y, while the drive systems account for about $98 \%$ of the power consumption. By using the EU27 power mix dataset (GABI data), this power consumption corresponds to a GWP of 5.17E+06 $\mathrm{kg} \mathrm{CO}_{2}$-eqv. over the 20 years of service life. Additionally, in terms of maintenance, it is assumed that at least the motors would have to be replaced once within the service life of the system, which leads to a total of $5.37 \mathrm{E}+06 \mathrm{~kg} \mathrm{CO}$-eqv. for the use stage.

\subsubsection{End of life}

The end-of-life stage was assessed in detail for all relevant components, but not considered in this system context because of low significance in the selected impact categories and very few options for the component manufacturer to influence it. For instance, in terms of GWP for motors, the manufacturing of a typical motor accounts for about 0.4 $\%$ of life time contributions, usage for about $99 \%$ and end-of-life for about $-0.3 \%$ (i.e. a benefit from the end-of-life stage due to recycling etc.). Such expectable benefits from end-of-life have not been considered, due to their low size. 
Auer J, Bey N, Schäfer J-M (2016); Combined Life Cycle Assessment and Life Cycle Costing in the EcoCare-Matrix: A case study on the performance of a modernized manufacturing system for glass containers Journal of Cleaner Production, Vol. 141, 10 January 2017, pp. 99-109 (online 1 Sept. 2016) http://dx.doi.org/10.1016/j.jclepro.2016.08.096

\subsubsection{Summary of the LCA part}

Based on the LCAs of various components used to modernize a glass container manufacturing system, it can be seen that the use stage is by far the most significant life cycle stage in terms of the potential environmental impact. This is due to the drive systems and their energy consumption during use. In terms of absolute GWP numbers, the optimization of the manufacturing system through improved automation, motion control and servo drives, accounts for about $2.09 \mathrm{E}+05 \mathrm{~kg} \mathrm{CO}$-eqv., leading to a reduction of $1.86 \mathrm{E}+06 \mathrm{~kg} \mathrm{CO}_{2}$-eqv., which represents a reduction of about $26 \%$. In total, neglecting the potential benefit as a result of the end-of-life treatment of $-0.3 \%$, it can be stated that the manufacturing stage of the servo drive components accounts for about $4 \%$ and usage for about $96 \%$ of the total GWP.

From a different perspective, the higher energy efficiency and the productivity (performance) that were achieved by modernizing the system result in the GWP of the final glass container being reduced by approximately $40 \%$. The ecological payoff period was calculated to be two years, as about 100 tons of $\mathrm{CO}_{2}$-eqv. are saved per year as a result of the modernization, accounting for 200 tons of $\mathrm{CO}_{2}$-eqv. in manufacturing.

\subsection{Life cycle costing}

For the LCC, costs were derived using a cost breakdown structure, the results of which are summarized in Table 5. It has to be mentioned in this context that in terms of the LCC of the case study, the view taken was that of modernizing an existing system, not directly comparing two alternative options involving "greenfield" plants. The objective was to evaluate the economic benefits in terms of a refurbishment. In the context of "greenfield", solutions including servo drives are expected to be favorable even with regard to environmental and financial aspects. In addition to the energy costs as well as the investment costs for servo drive components, which were needed for modernization, all other costs were estimated based on experience. The peripherals were omitted from the calculation, assuming that they would be kept in the case of a system modernization or refurbishment. End-of-life treatment was not considered either since component manufacturers can hardly influence the situation in this stage - and therefore no robust data is available. Further, it is assumed that there's no significant difference between the systems, and usually the disassembly and end-of-life treatment has a positive financial impact due to the high quality of materials used in such a system. 
Auer J, Bey N, Schäfer J-M (2016); Combined Life Cycle Assessment and Life Cycle Costing in the EcoCare-Matrix: A case study on the performance of a modernized manufacturing system for glass containers Journal of Cleaner Production, Vol. 141, 10 January 2017, pp. 99-109 (online 1 Sept. 2016) http://dx.doi.org/10.1016/j.jclepro.2016.08.096

Table 5: Summarized cost allocation derived from a cost breakdown structure for life cycle costing

\begin{tabular}{|c|c|c|c|c|}
\hline \multirow[t]{2}{*}{$\begin{array}{l}\text { Cost alloca- } \\
\text { tion }\end{array}$} & \multicolumn{2}{|c|}{$\begin{array}{l}\text { System A: } \\
\text { IS with pneumatic / hydraulic actua- } \\
\text { tors }\end{array}$} & \multicolumn{2}{|c|}{$\begin{array}{l}\text { System B: } \\
\text { IS with IDS components }\end{array}$} \\
\hline & Parameter $[k €]$ & Remark & Parameter $[k €]$ & Remark \\
\hline Machines & 100 & $\begin{array}{l}\text { Exchange of } \\
\text { pneumatic / hydrau- } \\
\text { lic actuators }\end{array}$ & 300 & $\begin{array}{l}\text { Exchange of } \\
\text { pneumatic / hydrau- } \\
\text { lic actuators with } \\
\text { servo motors }\end{array}$ \\
\hline Installation & 10 & $\begin{array}{l}\text { once per service } \\
\text { life, } 10 \% \text { of In- } \\
\text { vestment }\end{array}$ & 30 & $\begin{array}{l}\text { once per service } \\
\text { life, } 10 \% \text { of in- } \\
\text { vestment }\end{array}$ \\
\hline Maintenance & 40 & $20 \mathrm{k} € / \mathrm{a}$ & 20 & $10 \mathrm{k} € / \mathrm{a}$ \\
\hline Spare parts & 50 & $\begin{array}{l}\text { Exchange of } \\
\text { pneumatic cylinders }\end{array}$ & 100 & $\begin{array}{l}\text { Exchange of mo- } \\
\text { tors }\end{array}$ \\
\hline $\begin{array}{l}\text { Energy } \\
\text { (electric } \\
\text { power, kWh) }\end{array}$ & 1,800 & $\begin{array}{l}1.50 E+07 \quad k W h \quad \text { * } \\
0.12 € / k W h\end{array}$ & 1,284 & $\begin{array}{l}1.07 E+07 \quad k W h \text { * } \\
0.12 € / k W h\end{array}$ \\
\hline Total & 2,360 & & 1,910 & \\
\hline
\end{tabular}

The basic principle for estimating the life cycle costs was that the costs for pneumatic components are about one third of those for the electronic components, but maintenance is usually higher in a manufacturing system dominated by pneumatic and hydraulic actuators. In the study, maintenance costs for System A were assumed to be double those for System B. In order to make a proper comparison with the servo drive system, regarding the installation, it was assumed for the pneumatically driven system that at least the actuators would have to be replaced by servo drive components when modernizing. For an operating time of 20 years, it was assumed that at least some components, e.g. the motors and the pneumatic actuators, would have to be exchanged after 10 years of operation. The ZVEI LCC analysis tool (ZVEI, 2011) was populated based on the CBS and depreciation for the investment (10\% of the investment for 10 years) was taken into account. A comparison of the LCC of the two systems over the life cycle stages is shown in Figure 7 and the corresponding cash value, based on 20 years of service life is shown in Figure 8. 
Auer J, Bey N, Schäfer J-M (2016); Combined Life Cycle Assessment and Life Cycle Costing in the EcoCare-Matrix: A case study on the performance of a modernized manufacturing system for glass containers Journal of Cleaner Production, Vol. 141, 10 January 2017, pp. 99-109 (online 1 Sept. 2016) http://dx.doi.org/10.1016/j.jclepro.2016.08.096

Based on this LCC, the modernized System B performs about $19 \%$ better than the previous system, resulting in savings of about 450,000 € over 20 years of lifetime. Taking the cash value of the energy costs into account, System B outperformed system A by $29 \%$. The payback time for the modernization was calculated to be around 5.34 years.

\subsection{Eco-Care-Matrix}

The ECM for the two systems in Figure 9 shows the environmental and economic improvements of the system when using servo drive components. The reference, System A, located at the center of the matrix, is responsible for energy costs of more than 1.5 million $€$ and the discharge of more than 7,243 tons $\mathrm{CO}_{2}$-eqv. over the operating time of 20 years. The benefit of the enhanced system with servo drive components (System B), is represented by scenario 1. Concerning environmental benefits in terms of GWP, the introduction of motion control and servo drives lead to an "improvement" of about 26 \% (a reduction of about 1.9 million $\mathrm{kg} \mathrm{CO}_{2}$-eqv. in absolute terms), while the customer benefit increases by $19 \%$ (just taking into account the cost savings).

Linking these results to the output of the manufacturing system, the carbon footprint of the container glass bottles produced on System B is reduced by about $40 \%$ compared to System A. 
Auer J, Bey N, Schäfer J-M (2016); Combined Life Cycle Assessment and Life Cycle Costing in the EcoCare-Matrix: A case study on the performance of a modernized manufacturing system for glass containers Journal of Cleaner Production, Vol. 141, 10 January 2017, pp. 99-109 (online 1 Sept. 2016) http://dx.doi.org/10.1016/j.jclepro.2016.08.096

\section{Discussion}

It first has to be stated that this case study was carried out in an application-specific context (i.e. a specific technology) and in a European setting. The results will be different depending on the particular region and application - and will especially depend on the power grid mix and the associated environmental impact. On the application side, in a less dynamic production flow, i.e. one with longer holding intervals, the differences between pneumatic and servo solutions can be expected to be less, as (Hirzel et al., 2014) pointed out when comparing pneumatic to electric actuators.

In terms of the financial benefits of the investment regarding modernization, it has to be emphasized that some parameters in the study were estimated based on the assumption that the manufacturing peripherals were identical. For instance, instead of modernizing a manufacturing system (one of the scenarios in this case study), if a completely new manufacturing system without compressed air is built, all of the auxiliary equipment required to provide compressed air can be reduced. This results in even higher savings. On the other hand, if there is a very effective compressed air system in place and different process settings, savings might be lower and the payback time for the investment will be longer. Additionally, the economic framework of the company will significantly influence the payback time of the investment, for instance individual interest rates, depreciation practices and discounts negotiated for the investment, etc. Finally, the current and future market situation will also have an impact here, especially how electricity prices and inflation rates will develop. Hence, it can be said that the LCC approach was too generalized to obtain an impression about investing in a refurbishment, because in reality, the specific financial pay-off will depend on the very individual situation of the particular company.

The results of the environmental performance evaluation based on life cycle assessment clearly showed the high significance of the use stage. Therefore, the chosen power mix and levers for increasing energy efficiency have a high influence on the potential environmental impact. In the current European average power mix, coal, oil, and natural gas still play a big role as primary energy sources and contribute to global warming, acidification and eutrophication being the most relevant impact categories. This will change due to an increasing share of renewables providing electric power and consequently declining climate relevant emissions from the power mix. Hence, other indicators/impact categories might be more relevant in the future, as well as other aspects of 
Auer J, Bey N, Schäfer J-M (2016); Combined Life Cycle Assessment and Life Cycle Costing in the EcoCare-Matrix: A case study on the performance of a modernized manufacturing system for glass containers Journal of Cleaner Production, Vol. 141, 10 January 2017, pp. 99-109 (online 1 Sept. 2016) http://dx.doi.org/10.1016/j.jclepro.2016.08.096

ecodesign (besides energy efficiency) tackling these impacts. Therefore, more impact categories than the energy-related ones used in this study should be taken into account in further studies, like for instance resource depletion and toxicity. In that context it has to be mentioned too that the results should then also be validated by applying different characterization models in order to take latest scientific developments into account, e.g. within toxicity-related impact categories.

The performance evaluation, as key parameter for the above-mentioned results, has been carried out by the system provider and was based on measurements in a defined application set-up, coming to an average in energy savings of $40 \%$ when comparing the two systems. There was no detailed data available concerning the individual process steps and the associated operations. Therefore, the results shouldn't be transferred to any other, principally comparable manufacturing system or generally on the discussion of efficiency of pneumatic vs electric drives. In this context it has to be assumed that the relevant parameters, e.g. cycle time and power demand, may have been favorable for electric drives, but again these aspects were not in the scope of this case study. 
Auer J, Bey N, Schäfer J-M (2016); Combined Life Cycle Assessment and Life Cycle Costing in the EcoCare-Matrix: A case study on the performance of a modernized manufacturing system for glass containers Journal of Cleaner Production, Vol. 141, 10 January 2017, pp. 99-109 (online 1 Sept. 2016) http://dx.doi.org/10.1016/j.jclepro.2016.08.096

\section{Conclusions and Further Work}

The analysis of the complete modernized manufacturing system for container glass bottle production showed that the largest contribution to the environmental impact and to the economic costs is related to the energy requirements during the use stage. As a consequence, the highest opportunities for reducing potential environmental impact and costs, can be realized by upgrading the system to include motion control and servo drives. The underlying LCA of the manufacturing system itself was a rather extensive case study, taking into account more than 600 components, enabling to allocate the environmental impacts, as well as the benefits to certain functionalities of the system. It can be concluded that any intelligence (controls, communication) which may be added into a comparable manufacturing system, that improves (energy) efficiency and throughput, will pay off in terms of cost savings and the reduction of (potential) environmental impact. In terms of the cost-benefit evaluation it can be concluded that even a refurbishment of an existing system can be a viable option for improving performance. In terms of environmental aspects, manufacturing, as well as the end-of-life stage can almost be neglected in an industrial context with service lives from 10 to 20 (or even 30) years and the corresponding high quality requirements, realized through high quality materials, service and repairability. Similar conclusions were drawn in other case studies in different application contexts, e.g. pumps (Smith, 2011) and compressors (Siemens, 2014), and today even reflected in a corresponding standard for drive systems (EN50598-1, 2015) so at this point the importance of the message - "carefully consider the application setup and scenario" - has to be stressed to avoid counterproductive suboptimizations at the component level in the system context or micro optimization.

Therefore, it can be concluded that when using LCA as a method for ecodesign at the system level or in the context of the product environmental footprint (EC, 2013), valid simplifications are necessary for the assessment of these life cycle stages. To quantify it: Out of the 632 components and devices used to modernize the system, approximately 300 would have to be assessed in detail (full scale LCA); Using $52 \mathrm{~h}$ as an average mean time for conducting the LCA based on (Auer et al., 2014) this leads to 15,600 working hours for LCA experts to carry out the various studies; using $60 €$ as hourly wages, this leads to costs of 936,000 € for carrying out the LCA for the manufacturing system. Surely this is "overkill” for the methodology in this context and considerable thought has to be given regarding its application. 
Auer J, Bey N, Schäfer J-M (2016); Combined Life Cycle Assessment and Life Cycle Costing in the EcoCare-Matrix: A case study on the performance of a modernized manufacturing system for glass containers Journal of Cleaner Production, Vol. 141, 10 January 2017, pp. 99-109 (online 1 Sept. 2016) http://dx.doi.org/10.1016/j.jclepro.2016.08.096

For companies using LCA to support ecodesign and to support sustainability messages, the key recommendation by the authors is to (i) adapt the methodology to the system perspective and to (ii) be able to map the applications in this context. For instance, the enhancement of system engineering tools with relevant environmental indicators would be an option to promote ecodesign on a larger scale than just providing data for up to 30 different environmental impact categories as is the case in some environmental product declarations.

Concerning the future work, the applied eco-efficiency analysis tool, the ECM, is meant to be further developed for optimizing the IPSS of Siemens, the Integrated Drive System, in regard to the included product and service portfolio. The further development of the method should aim at combining technical, economic and environmental aspects in regard to the targeted application and thus to further optimize the offering, for instance by identifying and evaluating additional portfolio elements or further integration needs. Based on the needs of an application, a solution can be derived from the existing system components. By applying LCC and LCA (as underlying methods of ECM) drivers for cost and environmental impacts (e.g. in investment or operating costs, energy consumption related emissions or resource consumption) can be identified. Based on this analysis e.g. an additional portfolio element could then be identified and the improvement evaluated again by LCC and LCA using approximations and/or reference data. The ECM could then be used to display the options in a comparative view with the initial solution as reference point. This would even me more interesting if more than two options should be compared. Here research could address the combination of the ECM with multi-attribute decision analysis. In any case this requires switching from a retrospective, as in this case study, to a foresight application of the eco-efficiency tool. Both methodologies underlying the ECM, LCA and LCC, are capable of handling scenarios, which is a core requirement in that context. However, especially for the LCA - or more generally, for the evaluation of the environmental aspects - simplifications or rather smart approaches are necessary, balancing efficiency with accuracy, to be able to build a consistent and flexible model of the IPSS.

In regard to the evaluation of the environmental performance of the solution, also further work has to be done on defining normalization and weighting schemes to enable a robust decision support based on different, and maybe contradictory, impact indicators. Additionally, another core activity will be the integration of the ECM tool, or at least certain aspects of it, into product life cycle management (PLM) tools, as well as into 
Auer J, Bey N, Schäfer J-M (2016); Combined Life Cycle Assessment and Life Cycle Costing in the EcoCare-Matrix: A case study on the performance of a modernized manufacturing system for glass containers Journal of Cleaner Production, Vol. 141, 10 January 2017, pp. 99-109 (online 1 Sept. 2016) http://dx.doi.org/10.1016/j.jclepro.2016.08.096

system engineering tools and marketing concepts in order to consider and show the benefits of the IPSS application specifically. 
Auer J, Bey N, Schäfer J-M (2016); Combined Life Cycle Assessment and Life Cycle Costing in the EcoCare-Matrix: A case study on the performance of a modernized manufacturing system for glass containers Journal of Cleaner Production, Vol. 141, 10 January 2017, pp. 99-109 (online 1 Sept. 2016)

\section{References}

(Auer et al., 2014) Auer, Zintl, Berninger, Bey: Comparison of two different approaches for a simplified life cycle assessment of electronics, Session 3.1.: Sustainability and Environmental Assessment, lecture 3.1.2., CARE Innovation 2014 Conference, Vienna, (2014)

(Bey and McAloone, 2006) Bey, McAloone: From LCA to PSS - Making leaps towards sustainability by applying product/service-system thinking in product development, Proceedings of LCE 2006, pp. 571 - 576, $13^{\text {th }}$ CIRP International Conference on Life Cycle Engineering. (2006)

(Brondi and Carpanzano, 2011) Brondi, Carpanzano: A Modular Framework for LCABased Simulation of Production Systems, CIRP Journal of Manufacturing Science and Technology, Vol. 4 (3), pp. 305 - 312. (2011)

(Chomkhamsri and Pelletier, 2011) Chomkhamsri, Pelletier: Analysis of existing environmental footprint methodologies for products and organizations: Recommendations, rationale and alignment, Institute for Environment and Sustainability. European Commission Joint Research Center (2011)

(Diehm, 2007) Diehm: IS machines: 80 years of continuous improvement. Glass International, Vol. 30, No. 6, pp. 23 - 6. (2007)

(Dobranskyte-Niskota et al., 2007) Dobranskyte-Niskota, Perujo, Pregl: Indicators to assess sustainability of transport activities. European Commission. Joint Research Center, Institue for Environment and Stustainability, Ispra, Italy. (2007)

(EC, 2010) European Commission - Joint Research Centre - Institute for Environment and Sustainability: International Reference Life Cycle Data System (ILCD) Handbook General guide for Life Cycle Assessment - Detailed guidance. First edition March 2010. EUR 24708 EN. Luxembourg. Publications Office of the European Union. (2010)

(EC, 2011) European Commission: A resource-efficient Europe - Flagship initiative under the Europe 2020 strategy, Communication from the Commission to the European Parliament, the Council, the European Economic and Social Committee and the Committee of Regions. (2011) 
Auer J, Bey N, Schäfer J-M (2016); Combined Life Cycle Assessment and Life Cycle Costing in the EcoCare-Matrix: A case study on the performance of a modernized manufacturing system for glass containers Journal of Cleaner Production, Vol. 141, 10 January 2017, pp. 99-109 (online 1 Sept. 2016) http://dx.doi.org/10.1016/j.jclepro.2016.08.096

(EC, 2013) European Commission: Building the Single Market for Green Products Facilitating better information on the environmental performance of products and organisations. Communication/* COM/2013/0196 final */ (2013)

(Ehrenfeld, 2005) Ehrenfeld: Eco-efficiency - Philosophy, Theory, and Tools, Journal of Industrial Ecology, Vol. 9 (4), pp. 6 - 9. (2005)

(EN50598-1, 2015) EN50598-1:2015 - Ecodesign for power drive systems, motor starters, power electronics and their driven applications (2015)

(EN50598-3, 2015) EN50598-3:2015 - Ecodesign for power drive systems, motor starters, power electronics and their driven applications (2015)

(EU, 2015) http://ec.europa.eu/eurostat/statisticsexplained/index.php/Energy_price_statistics; Accessed 08.10.2015

(Farla et al., 1997) Farla, Blok, Schipper: Energy efficiency developments in the pulp and paper industry - A cross-country comparison using physical production data, Energy Policy, Vol. 25, Nos. 7 - 9, pp. 745 - 758. (1997)

(Hauschild et al., 2005) Hauschild, Jeswiet, Alting: From Life Cycle Assessment to Sustainable Production: Status and Perspectives, CIRP Annals - Manufacturing Technology, Vol. 54 (2), pp. 1 - 21. (2005)

(Hermann et al., 2012) Hermann, Gama, Helman: Calculating the carbon footprint of electronic products with life cycle assessment, PE International white paper. (2012) (Hirzel et al., 2014) Hirzel, Hettesheimer, Schroeter (2014): Electric or pneumatic? Comparing electric and pneumatic linear drives with regard to energy efficiency and costs, Proceedings of the eceee 2014 Industrial Summer Study on energy efficiency, pp. 475 - 485, Arnhem, Netherlands. (2014)

(Hui and Mohammed, 2015) Hui, Mohammed: The Role of Cost Breakdown Structure in Life Cycle Cost Model. Jurnal Teknologi, Vol. 74:2, pp. 117 - 121. (2015)

(Hülsemeyer et al., 2015) Denkena, Helmecke, Hülsemeyer: Energy efficient machining of Ti-6Al-4V, CIRP Annals - Manufacturing Technology, Vol. 64, pp. 61 - 64. (2015)

(Huppes and Ishikawa, 2007) Huppes, Ishikawa: An introduction to quantified ecoefficiency analysis, Eco-efficency in industry and science, Vol. 22, Quantified EcoEfficency - An Introduction with Applications, Chapter 1, pp. 1 - 38, Springer Netherlands. (2007) 
Auer J, Bey N, Schäfer J-M (2016); Combined Life Cycle Assessment and Life Cycle Costing in the EcoCare-Matrix: A case study on the performance of a modernized manufacturing system for glass containers Journal of Cleaner Production, Vol. 141, 10 January 2017, pp. 99-109 (online 1 Sept. 2016) http://dx.doi.org/10.1016/j.jclepro.2016.08.096

(ISO 14040, 2006) Environmental management - Life cycle assessment - Principles and framework (ISO 14040:2006); - Requirements and guidelines (ISO 14044:2006)

(Kádárová et al., 2015) Kádárová, Kobulnicky, Teplicka: Product Life Cycle Costing, Applied Mechanics and Materials, Vol. 816, pp. 547 - 554. (2015)

(Lindahl et al., 2014) Lindahl, Sundin, Sakao: Environmental and Economic Benefits of Integrated Product-Service Offerings Quantified with Real Business Cases. Journal of Cleaner Production Vol. 64, pp.288 - 296. (2014)

(Mao et al., 2013) Mao, Zeng, Hu, Zhou, Xing, Liu: Co-control of local air pollutants and $\mathrm{CO}_{2}$ in the Chinese iron and steel industry, Environ. Science Technology, Vol. 47 (21), pp. $12002-12020$. (2013)

(Meier et al. 2010) Meier, Roy, Seliger: Industrial Product-Service Systems - IDS², Annals of CIRP Vol. 59(2), pp. 607 - 627. (2010)

(Moah and Kanaroglou, 2009) Moah, Kanaroglou: A Tool for Evaluating Urban Sustainability via Integrated Transportation and Land Use Simulation Models. Urban Environment, Vol. 3, pp. 28 - 46. (2009)

(Nambiar, 2010) Nambiar: Challenges in Sustainable Manufacturing, Proceedings of the 2010 International Conference on Industrial Engineering and Operations Management, lecture 266, Dhaka, Bangladesh. (2010)

(Pulselli et al., 2009) Pulselli, Ridolfi, Rugani, Tiezzi: Application of life cycle assessment to the production of man-made crystal glass, International Journal of Life Cycle Assessment, Vol. 14, pp. 490 - 501. (2009)

(Sarapulov et al., 2015) Linkov, Olizarenko, Radionov, Sarapulov: Energy-efficient power supply systems for mines, International Conference on Industral Engineering, Procedia Engineering, Vol. 129, pp. 63 - 68. (2015)

(Siemens, 2014) Reuss, Georg: Energy-saving glass pressing. Siemens Advance 03/2014; pp. 16 - 17, www.industry.siemens.com/topics/global/en/magazines/advance/advancearchive/Documents/advance-2014-3-en.pdf . Accessed on 18.12.15.

(Siemens, 2015) Siemens: 40 \% energy savings with integrated drive systems, blogs.siemens.com/competitive-industries/stories/830-40-percent-energy-savings-withintegrated-drive-systems. Accessed on 14.12.2015 
Auer J, Bey N, Schäfer J-M (2016); Combined Life Cycle Assessment and Life Cycle Costing in the EcoCare-Matrix: A case study on the performance of a modernized manufacturing system for glass containers Journal of Cleaner Production, Vol. 141, 10 January 2017, pp. 99-109 (online 1 Sept. 2016) http://dx.doi.org/10.1016/j.jclepro.2016.08.096

(SIZER, 2015) Siemens: SIZER for Siemens drives, w3.siemens.com $/ \mathrm{mcms} / \mathrm{mc}-$ solutions/en/engineering-software/drive-design-tool-sizer/Pages/drive-design-toolsizer.aspx; Accessed 16.12.2015

(Sklostroj, 2015) Sklostroj: IS Machines, Fehler! Hyperlink-Referenz ungültig.www.sklostroj.cz/userfiles/file/AL/IS\%20Machines.pdf. Accessed on 14.12.2015 (Sleeswijk et al., 2007) Sleeswijk, van Oers, Guinée, Struijs, Huijbergts: Normalisation in product life cycle assessment: An LCA of the global and European economic systems in the year 2000. Science of the Total Environment 390, 2008

(Smith, 2011) Smith, Cecil: Things to Watch Out for with Variable-Speed Pumps, www.sustainableplant.com/2011/04/things-to-watch-out-for-with-variable-speedpumps/Tab/Article

(Stoppato, 2006) Stoppato: Life cycle assessment of photovoltaic electricity generation, Energy, Vol. 33, pp 224 - 232. (2006)

(Strømman et al., 2012) Hawkins, Singh, Majeau-Bettez, Hammer Strømman: Comparative Environmental Life Cycle Assessment of Conventional and Electric Vehicles, Journal of Industrial Ecology, Vol. 17 (1), pp. 53 - 64. (2012)

(Thinkstep, 2015) Thinkstep: GaBi Software, www.gabisoftware.com/international/index/ ; Accessed on 12.12.2015

(Trifonova and Ishun'kina, 2007) Trifonova, Ishun’kina: Eco-compatibility assessment of container glass production, Ecological Issues, Glass and Ceramics, Vol. 64, Nos. 5 6, pp. 214 - 217. (2007)

(UN, 2013) United Nations, Department of Economic and Social Affairs: World Economic and Social Survey 2013 - Sustainable Development Challenges, United Nations publication, Sales No. E.13.11.C.1, ISBN 978-92-1-109167-0. (2013)

(Wegener et al., 2009) Wegener, Finkbeiner, Geiger, Olsen, Walachowicz: Comprehensive Approach to Energy and Environment in the Eco Care Program for Design, Engineering and Operation of Siemens Industry Solutions. RISO International Energy Conference, Pages: 45-52. (2009)

(Wegener et al., 2011) Wegener, D., Finkbeiner, M., Holst, J-C., Olsen, S. I., \& Walachowicz, F. (2011). Improving Energy Efficiency in Industrial Solutions - Walk the Talk. In Energy Systems and Technologies for the Coming Century: Proceedings. Risø International Energy Conference 2011, May 10 - 12. (pp. 187-196). Danmarks 
Auer J, Bey N, Schäfer J-M (2016); Combined Life Cycle Assessment and Life Cycle Costing in the EcoCare-Matrix: A case study on the performance of a modernized manufacturing system for glass containers Journal of Cleaner Production, Vol. 141, 10 January 2017, pp. 99-109 (online 1 Sept. 2016) http://dx.doi.org/10.1016/j.jclepro.2016.08.096

Tekniske Universitet, Risø Nationallaboratoriet for Bæredygtig Energi. (Denmark. Forskningscenter Risoe. Risoe-R; No. 1776(EN)).

(Woodward, 1997) Woodward: Life cycle costing - theory, information acquisition and application. International Journal of Project Management, Vol. 15, No. 6, pp. 335-344. (1997)

(ZVEI, 2011) ZVEI LCE tool: www.zvei.org/en/association/publications/Pages/EnergyEfficiency-Pays-Off.aspx ; Accessed on 11.11.2015 
Auer J, Bey N, Schäfer J-M (2016); Combined Life Cycle Assessment and Life Cycle Costing in the EcoCare-Matrix: A case study on the performance of a modernized manufacturing system for glass containers Journal of Cleaner Production, Vol. 141, 10 January 2017, pp. 99-109 (online 1 Sept. 2016) http://dx.doi.org/10.1016/j.jclepro.2016.08.096

\section{Figures}

Figure 1: Concept of individual section (IS) machines used in glass container manufacturing. This basic principle remains the same even after the modernization. Glass smelt gobs are distributed into forms, and compressed air or mechanical components are used to shape the container (hollow). After shaping, the containers are transported by a conveyor belt to ool down in an annealing lehr (controlled cool down).

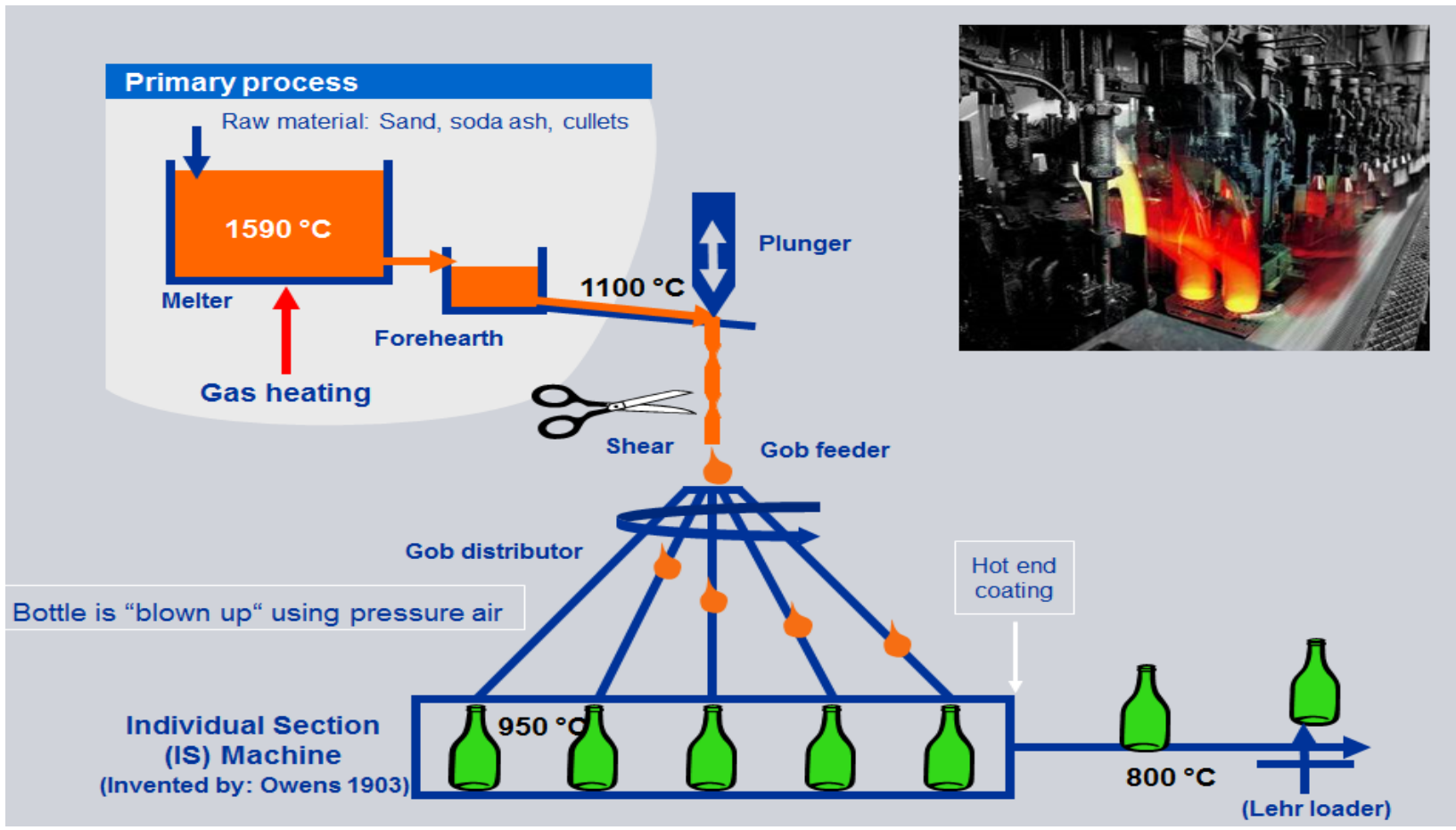


Auer J, Bey N, Schäfer J-M (2016); Combined Life Cycle Assessment and Life Cycle Costing in the EcoCare-Matrix: A case study on the performance of a modernized manufacturing system for glass containers Journal of Cleaner Production, Vol. 141, 10 January 2017, pp. 99-109 (online 1 Sept. 2016) http://dx.doi.org/10.1016/j.jclepro.2016.08.096

Figure 2: Overview of the key components of the modernized manufacturing system for glass containers, including process control, visualization, communications, and servo drive systems.

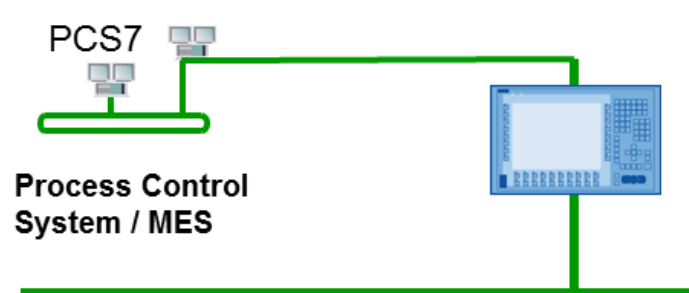

\section{Visualization \\ SIMATIC WinCC}
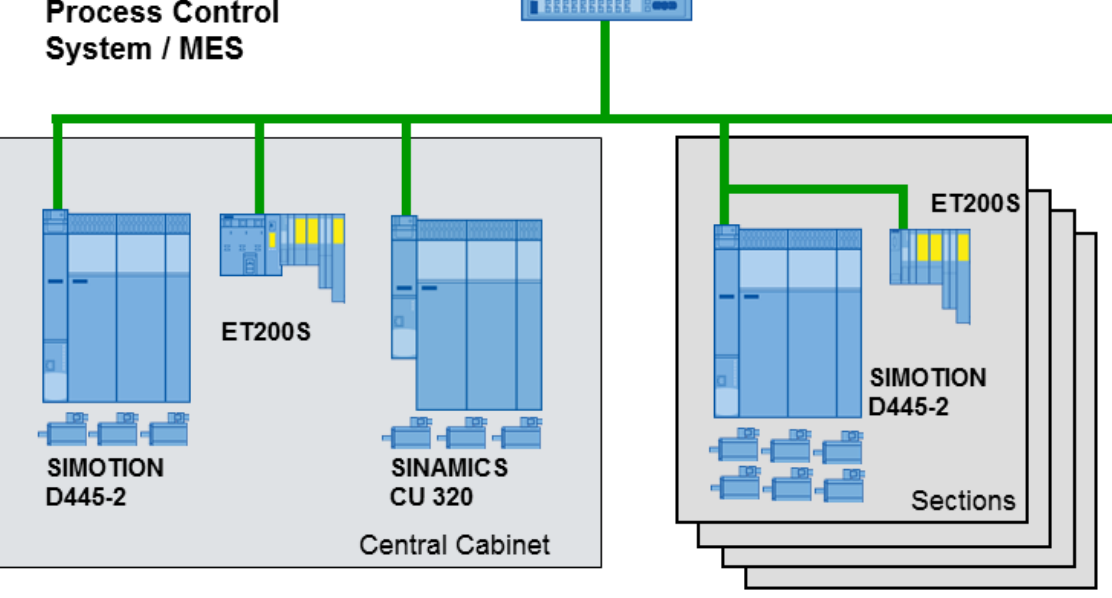

Distributed synchronous operation

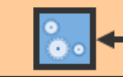

Plunger, shear, gob distributor

- I/O's
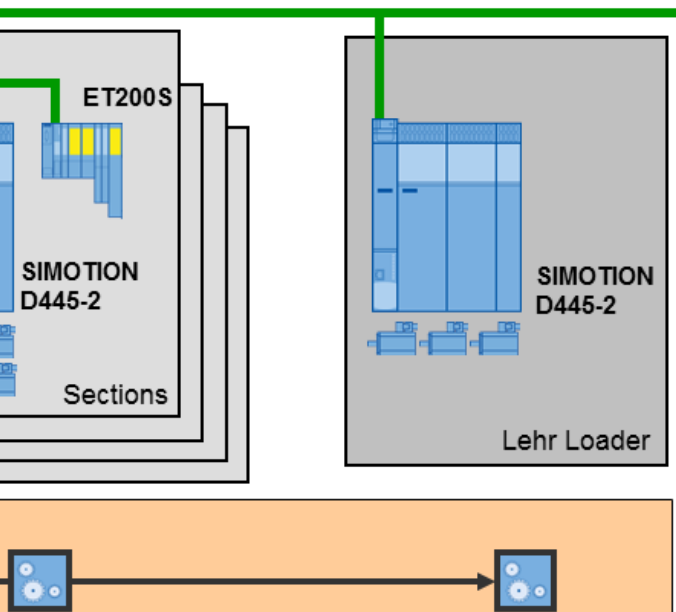

- Fan, Conveyors, etc. 
Auer J, Bey N, Schäfer J-M (2016); Combined Life Cycle Assessment and Life Cycle Costing in the EcoCare-Matrix: A case study on the performance of a modernized manufacturing system for glass containers Journal of Cleaner Production, Vol. 141, 10 January 2017, pp. 99-109 (online 1 Sept. 2016) http://dx.doi.org/10.1016/j.jclepro.2016.08.096

Figure 3: Visualization of how the system was innovated: Pneumatic components were replaced by servo drive components. The manufacturing periphery stays unchanged.
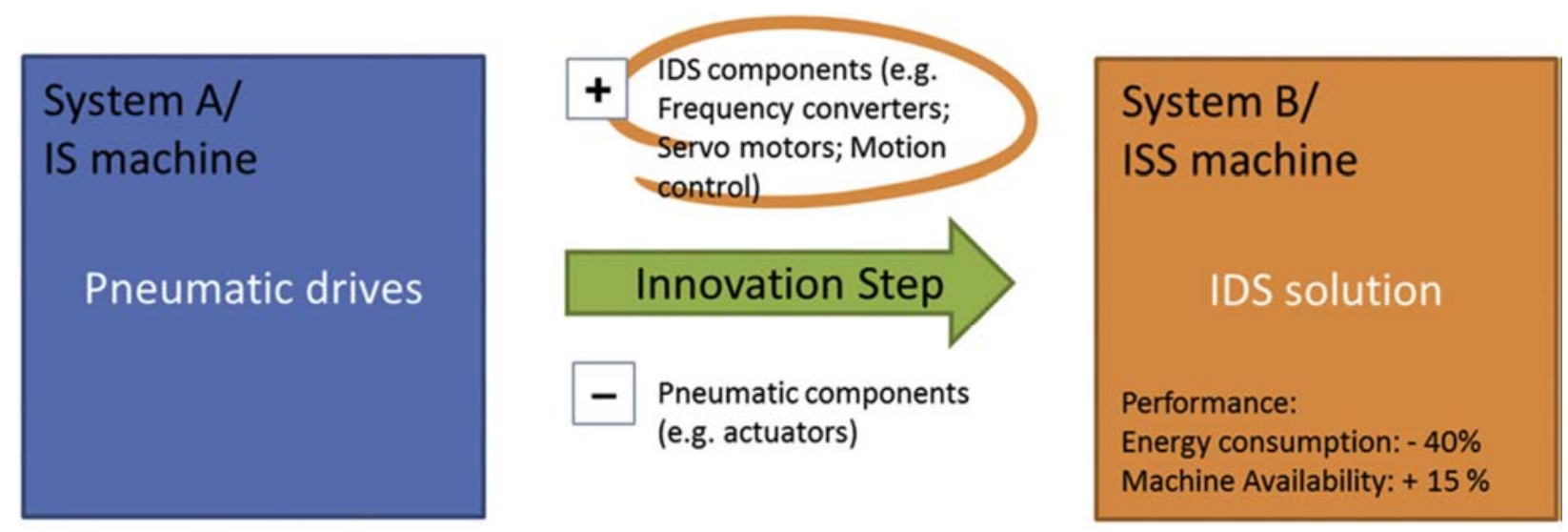

Manufacturing Periphery 
Auer J, Bey N, Schäfer J-M (2016); Combined Life Cycle Assessment and Life Cycle Costing in the EcoCare-Matrix: A case study on the performance of a modernized manufacturing system for glass containers Journal of Cleaner Production, Vol. 141, 10 January 2017, pp. 99-109 (online 1 Sept. 2016) http://dx.doi.org/10.1016/j.jclepro.2016.08.096

Figure 4: Example of the Eco-Care-Matrix. Systems are compared to a reference in terms of their economic and environmental performance, displayed as environmental and customer benefit. Basis for the performance comparison is the evaluation of the potential environmental impact based on LCA and economic performance via LCC.

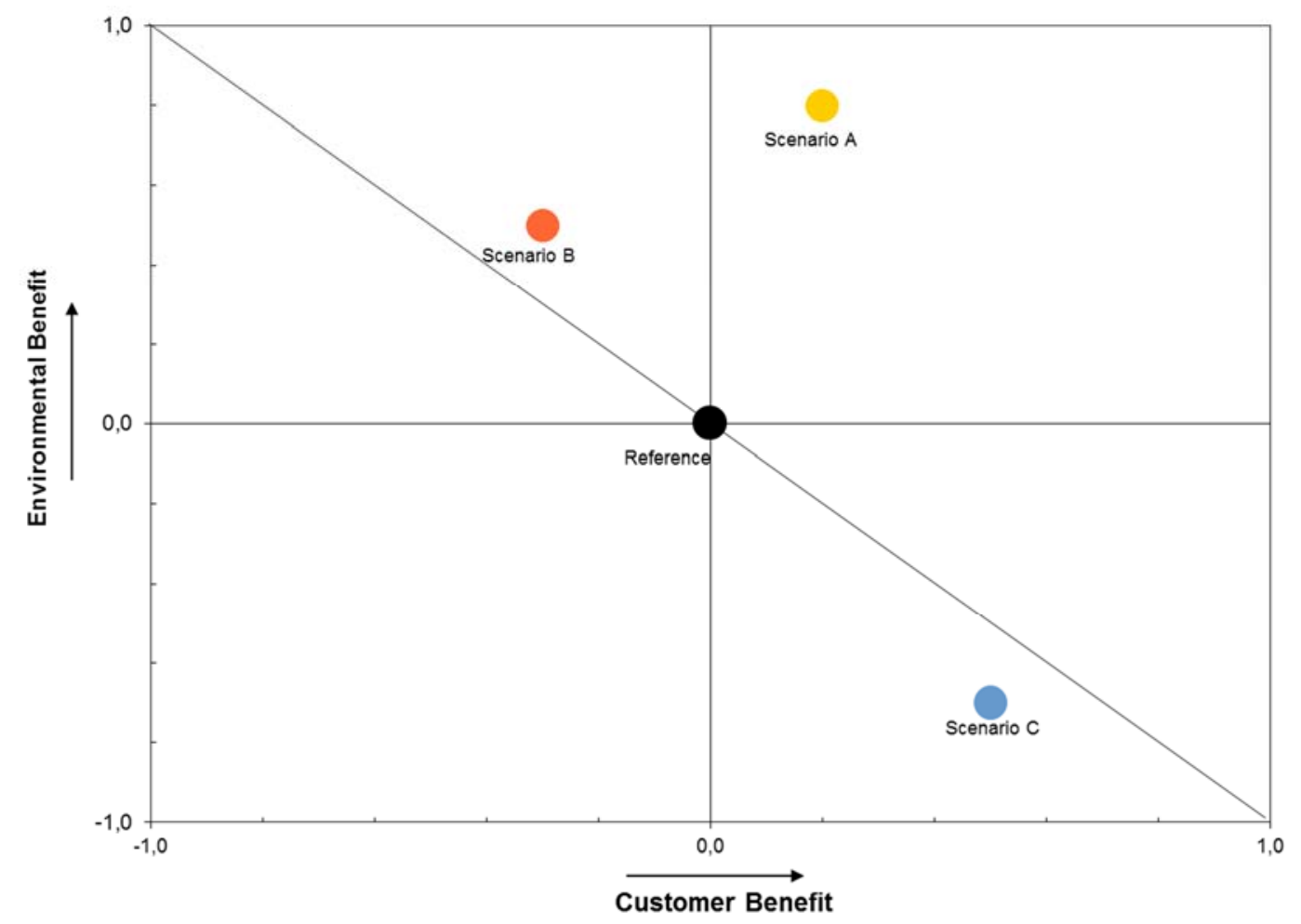


Auer J, Bey N, Schäfer J-M (2016); Combined Life Cycle Assessment and Life Cycle Costing in the EcoCare-Matrix: A case study on the performance of a modernized manufacturing system for glass containers Journal of Cleaner Production, Vol. 141, 10 January 2017, pp. 99-109 (online 1 Sept. 2016) http://dx.doi.org/10.1016/j.jclepro.2016.08.096

Figure 5 Graphic showing the contribution per function group to the impact categories as a percentage based on the normalized LCIA scores (weight as normalization factor) from Table 4.

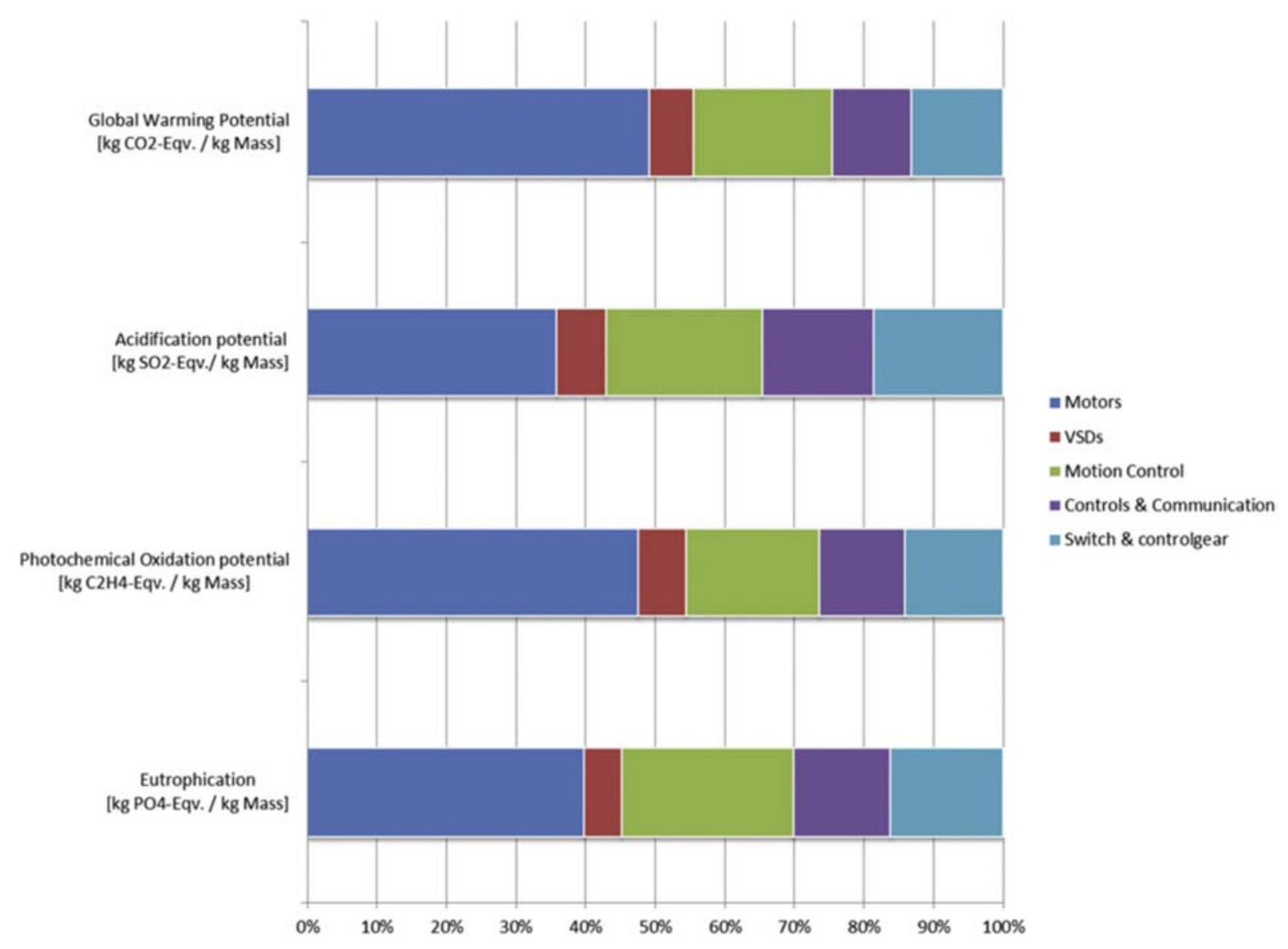


Auer J, Bey N, Schäfer J-M (2016); Combined Life Cycle Assessment and Life Cycle Costing in the EcoCare-Matrix: A case study on the performance of a modernized manufacturing system for glass containers Journal of Cleaner Production, Vol. 141, 10 January 2017, pp. 99-109 (online 1 Sept. 2016) http://dx.doi.org/10.1016/j.jclepro.2016.08.096

Figure 6: Graphic showing externally normalized LCIA scores of the manufacturing stage.

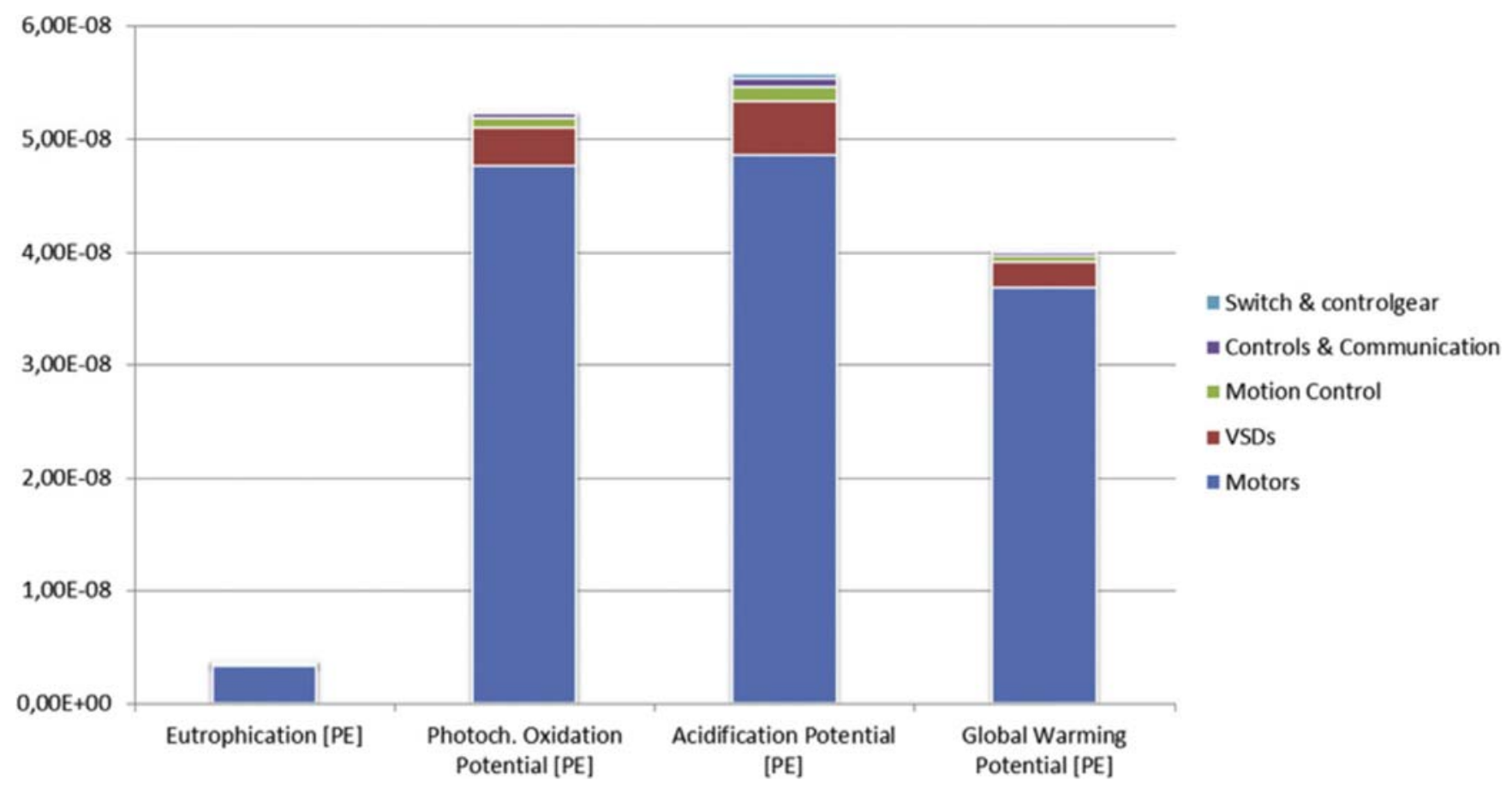


Auer J, Bey N, Schäfer J-M (2016); Combined Life Cycle Assessment and Life Cycle Costing in the EcoCare-Matrix: A case study on the performance of a modernized manufacturing system for glass containers Journal of Cleaner Production, Vol. 141, 10 January 2017, pp. 99-109 (online 1 Sept. 2016) http://dx.doi.org/10.1016/j.jclepro.2016.08.096

Figure 7: Comparison of life cycle costs over the individual stages at harmonized project duration.

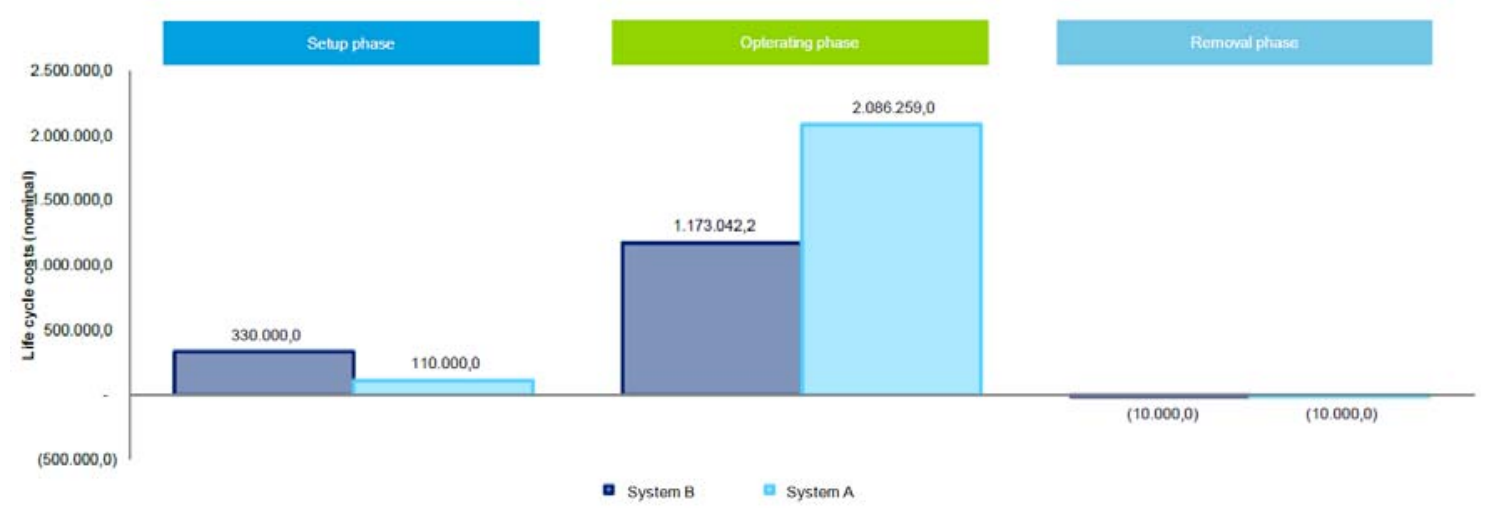


Auer J, Bey N, Schäfer J-M (2016); Combined Life Cycle Assessment and Life Cycle Costing in the EcoCare-Matrix: A case study on the performance of a modernized manufacturing system for glass containers Journal of Cleaner Production, Vol. 141, 10 January 2017, pp. 99-109 (online 1 Sept. 2016) http://dx.doi.org/10.1016/j.jclepro.2016.08.096

Figure 8: Cash value of life cycle costs at harmonized project duration.

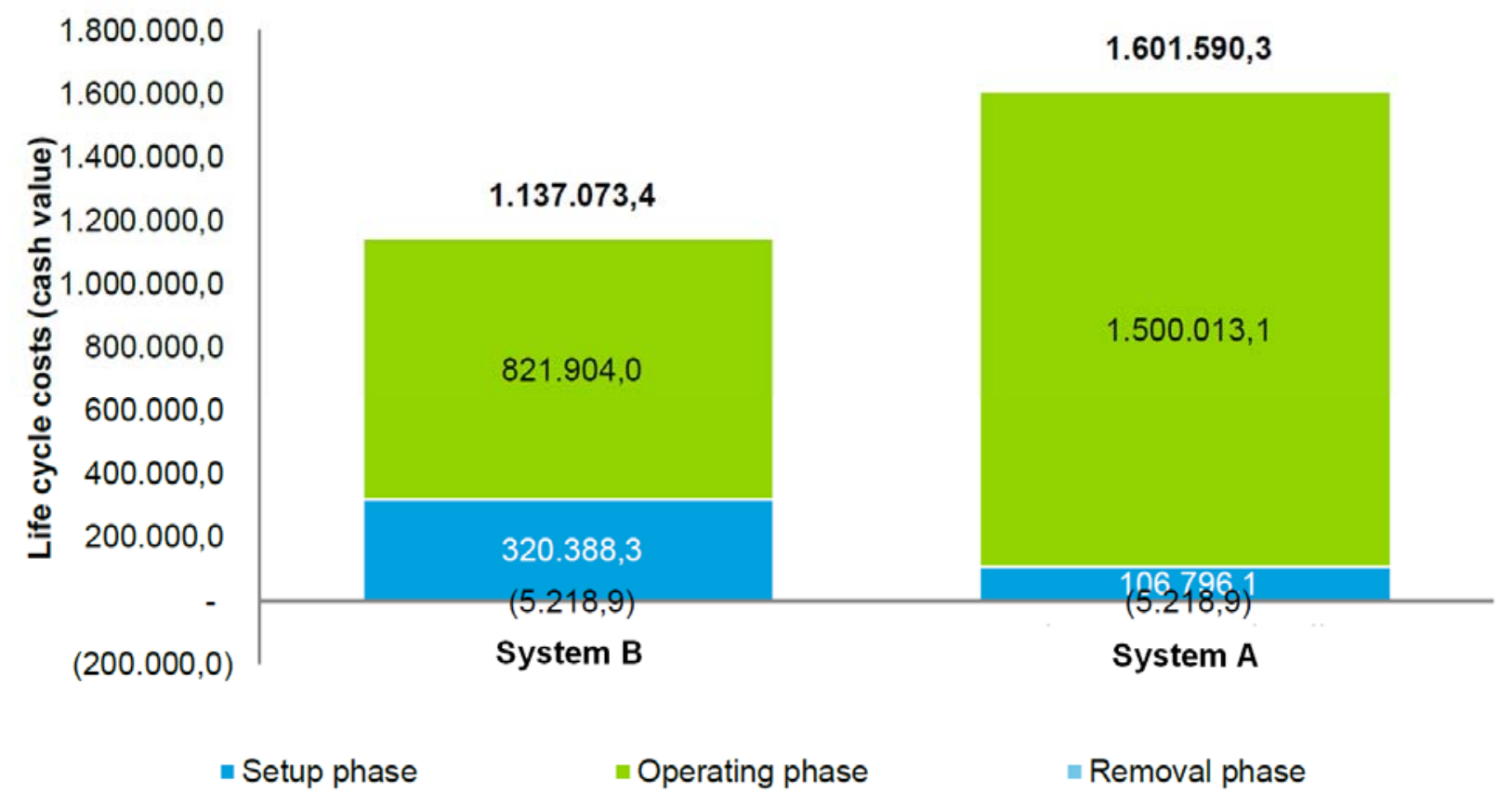


Auer J, Bey N, Schäfer J-M (2016); Combined Life Cycle Assessment and Life Cycle Costing in the EcoCare-Matrix: A case study on the performance of a modernized manufacturing system for glass containers Journal of Cleaner Production, Vol. 141, 10 January 2017, pp. 99-109 (online 1 Sept. 2016) http://dx.doi.org/10.1016/j.jclepro.2016.08.096

Figure 9: Eco-Care-Matrix comparison of the two systems. System A is the reference, system B, enhanced with servo drive components, provides economic and environmental benefit.

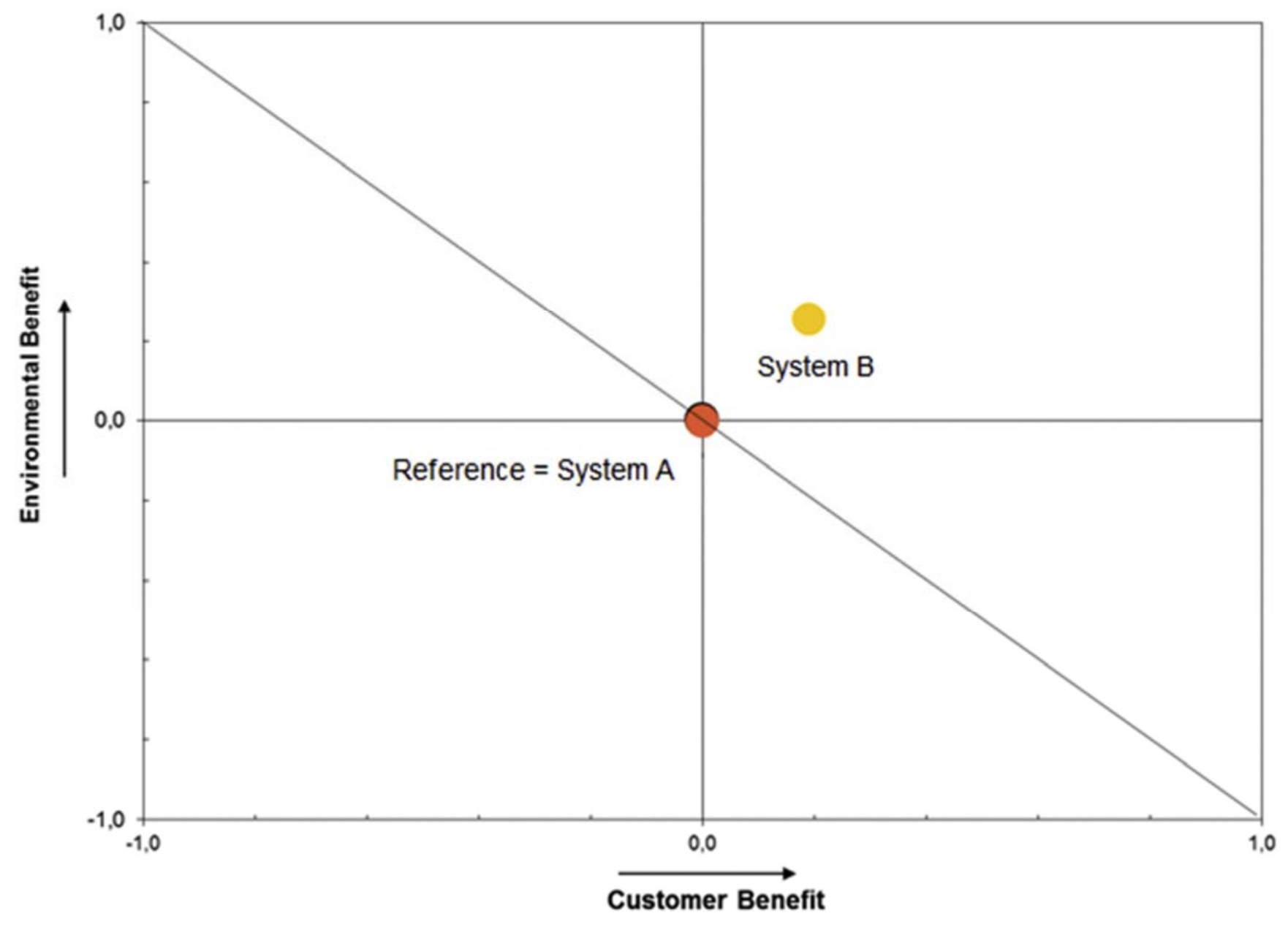

